\title{
Mesenchymal Stem Cell Signaling Pathway and Interaction Factors
}

\author{
Mezenkimal Kök Hücre Sinyal Yolakları ve Etkileşim Faktörleri
}

\author{
Gülsemin Çicek ${ }^{1}$, Selçuk Duman² (D), Tahsin Murad Aktan² (i) \\ ${ }^{1}$ Kanuni Sultan Süleyman Training and Research Hospital, IVF Center, İstanbul, Turkey \\ 2Department of Histology and Embryology, Necmettin Erbakan University, Meram School of Medicine, Konya, Turkey
}

Cite this article as: Çiçek G, Duman S, Aktan TM. Mesenchymal Stem Cell Signaling Pathway and Interaction Factors. Experimed 2019; 9(3): 120-9.

\begin{abstract}
Stem cells are self-renewing and undifferentiated cells with potential to transform into different types of functional cells. These cells can be classified into two types based on their roots; embryonic stem cells that originate from the inner cell mass of preimplanted embryos and can structure the tree germinal layers and, mature stem cells that have the potential to differentiate into at least one type of functional structure. Both types of the stem cells present their own characteristics and capacities by using their own signal pathways in the presence of very different interaction factors. Knowing the characteristics of those stem cells in detail will importantly contribute to therapeutics.
\end{abstract}

Keywords: Stem cell, signal pathway, interaction factors

\section{INTRODUCTION}

Cells respond at the receptor level to the signals coming from other cells or to the signals that are produced by themselves. This intercellular communication is called "cell signaling", and it is necessary for the functional regulation and integration of the organism. Signal mechanisms can be through endocrine, paracrine, autocrine, neurotransmitter or neuroendocrine ways (1). These signaling mechanisms are found in both embryonic stem cells and somatic cells (for ex. interleukin secretion of fibroblasts and stromal cells of the bone marrow). Mature stem cells, especially mesenchymal stem cells (MSCs), produce and secrete a large variety of cytokines, chemokines, growth factors, and they stimulate neighboring cells by a variety of mechanisms. While progenitor cells are being stimulated for proliferation and differentiation by the received signals, they also show anti-inflammatory and immune modulator effects by secreting growth factors and mediators (2). It is important to show the secretion of active mediators and their expressions biologically, in order to

\section{öz}

Kök hücreler, farklı tip fonksiyonel hücrelere dönüşme potansiyeline sahip, kendi kendini yenileyebilen ve farklılaşmamış hücrelerdir. Bu hücreler, kökenleri temel alınarak iki ana tip olarak sınıflandırılabilir: Preimplante embriyonun iç hücre kitlesinden köken alan ve 3 germ yaprağını da yapılandırabilecek embriyonik kök hücreler ile farklı doku ve organlarda bulunan, en az bir tip fonksiyonel yapıya farklılaşabilme kapasitesine sahip erişkin kök hücreler. Bu her iki kök hücre tipi de çok farklı etkileşim faktörleri varlığında kendi sinyal yollarını kullanarak kendi özelliklerini ve kapasitelerini sunar. Bu kök hücrelerin özelliklerini ayrıntılı olarak bilmek, terapötik maddelere önemli katkı sağlayacaktır.

Anahtar Kelimeler: Kök hücre, sinyal yolağı, etkileşim faktörleri

understand the biology of stem cells. The organization of the secretion of paracrine cytokines occurs by the influence of the microenvironment or by their impact on the microenvironment of the stem cell niches. Additionally, paracrine mediators have a role in pathological cases. The secretion of the paracrine factors as a response to tissue injury, activates the endogenous repair and regeneration mechanisms, and affects the cell survival. Stem cells and progenitor cells protect the tissue for their continuation of life by providing balance between proliferation and differentiation.

Secreted factors of the mature stem cells play an important role in the regenerative process seen after stem cell mobilization, while the proves supporting this hypothesis are increasing. MSCs, that are identified to be safer in the clinical use, are multipotent cells and they are easily obtained and produced. Treatments on the cellular level is mostly done by using autologous bone marrow MSC and fat tissue which reserves a large number of MSC when compared to bone marrow (3). A large part of the 
stem cells in the adipose tissue are located in the perivascular region (4), and they have a unique capacity for proliferation and transdifferentiation (5). MSCs have the capacity to differentiate into adipocyte, osteocyte, chondrocyte, myocyte and neuronal cell lines. This multipotent differentiation potential is achieved by effect of the large number of secreted cytokines and growth factors (6). Extracellular vesicles (EV) based on the MSCs are structures having therapeutic characteristics for many of the diseases. EVs secreted by the cells are generally called microvesicles, cellular based vesicles, microparticles, secreted vesicles and exosomes. EVs are important mediators of intercellular communication, both in physiological and pathological cases. Vesicle substance varies by cell types and physiological conditions; EVs contain various proteins, lipids and nucleic acids (7). Microvesicles are secreted by the activation of various cells like thrombocytes, endothelial cells, erythrocytes, monocytes, lymphocytes and leucocytes, or by apoptosis. EVs of 50-200 $\mathrm{mm}$ in diameter are called exosomes and, exosomes play an important role in intercellular communication (8). In addition to this, alterations in the cytokines and growth factors secreted by the MSCs can affect the (non-migratory) functions of the cell located in the tissue; those effects can even exist after the disappearance of MSCs (9). EVs include the proteins, RNAs and some undefined proteins in their structure, just like a cargo. The content of EV supports the proliferation of the cells, and also provides the inhibition of apoptosis by affecting intracellular signal pathways (8). The first study where this theory became true showed the effect of paracrine factors based on MSC on the myocardial ischemia reperfusion damage $(10,11)$. It showed that MSC exosomes from autologous origin are effective in enhancing the left ventricular diastolic function in myocardial damage (12). Zhang et al. (13) reported that EVs based on MSCs stimulate the proliferation of epidermal cells in burned skin. An important example is mRNAs of EV secreted from MSCs shown to have therapeutic effect on tissues that have acute renal damage. The mRNA shows its effect here by helping proliferation, transcription regulation and immune modulation $(14,15)$. Another example is the demonstration of mRNA transfer in the healing of acute lung injury. The mRNA of EVs with KGF (keratinocyte growth factor) is transferred to type II alveolar epithelium from bone marrow stem cells, and they are passed to the protein of type II alveolar epithelium. Increase of KGF protein in type II epithelium turns into an immune modulator effect and, its protective effect in acute lung injury takes place (16).

Various signal pathways are defined as the organizers of self-renewing and stemness in stem cells (Figure 1). Exosomes of the MSCs play an active role in the preservation of the characteristics, like differentiation capacity, self-renewing, stemness and prevention of early differentiation. Those characteristics of the stem cells are essential in development of cell-based therapies. However, it is necessary to optimize the differentiation poten-

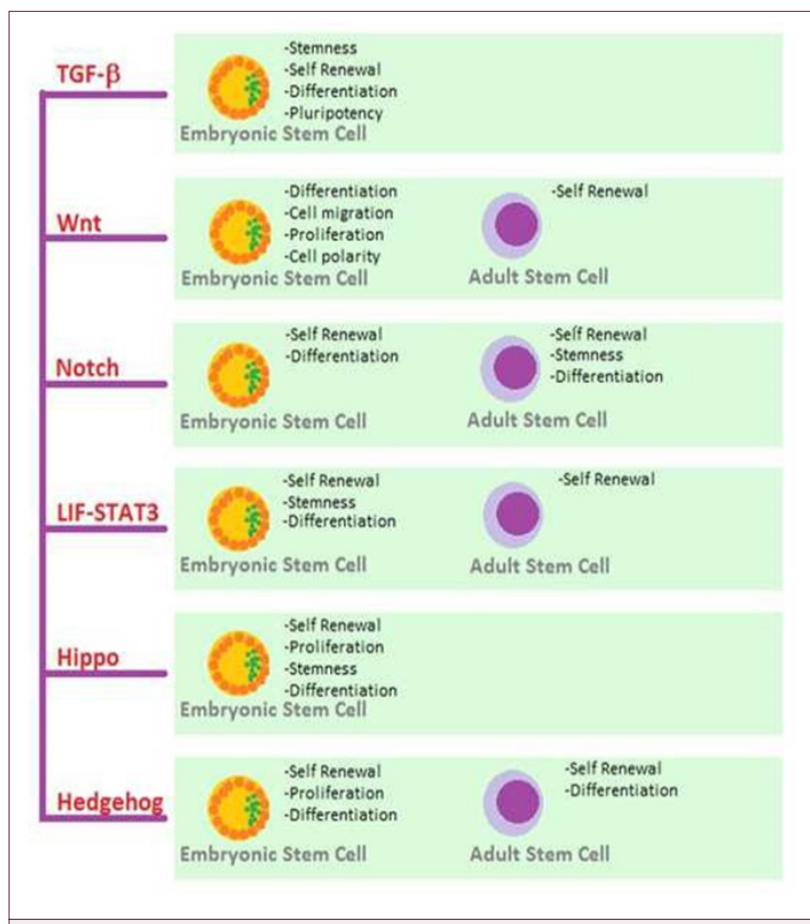

Figure 1. Main signal pathways having role on self-renewal and stemness of stem cell

tial and proliferation rate of MSCs in order to provide the therapeutic efficiency of MSCs.

While signal pathways, epigenetic modulators, cell cycle regulators and transcription factors regulate the balance between self-renewing and differentiation, reorganization for the repair will be shaped. There are many points and signal pathways defined in the human stem cells for stemness and self-renewing.

While the self-renewing concept of stem cells is defined by the continuity of proliferation, differentiation inhibition and apoptosis inhibition, signals related to this include chemical regulators (ex: Prostaglandins, retinoic acid), developmental regulators (ex: BMP- bone morphogenic protein), and signal pathways (ex: Wnt, Notch, Hedgegod signal pathways) (17). The stemness concept is regulated by extrinsic and intrinsic stimuli in stem cells (18). In the meantime, the achievement of the balance between self-renewing and differentiation in stem cells is carried out by the combination of asymmetric and symmetric cell division. Symmetrical division gives rise to two identical cells, while asymmetrical division gives rise to one stem cell and one progenitor cell (19). This discrepancy is also of special importance in embryonic development and cellular treatment periods.

Molecules having a central role in providing the stemness concept, which is predestinating the stem cell, are Oct4, SOX2, NANOG (20). These are main transcription factors regulating the pluripotentiality and self-renewing in the embryonic stem 
cell (21). Expression of Nanog is governed by Oct4, SOX2 (22). Oct4 is expressed highly in embryonic internal cell mass (23). SOX2 stimulates the differentiation in the neuronal ectoderm germ layer (21).

\section{TGF- $\boldsymbol{\beta}$ Signalling Pathway}

The transforming growth factor (TGF)- $\beta$ superfamily has more than 30 members. It plays a critical role in the regulation of cell growth, development and differentiation (24). It has 3 different subgroups: TGF- $\beta 1$, TGF- $\beta 2$ and TGF- $\beta 3$. TGF- $\beta$ super $\beta$ family includes TGF- $\beta$ and nodal pathways, which have the characteristics of self-renewal and stemness of stem cell and also, the BMP pathway which induces differentiation (25-27). The signal starts with the lig and based oligomerization of the serin/treonin receptor kinase. Together with the companionship of general signal transduction provider Smad4 to this phosphorylation, the SMAD molecules are translocated to the nucleus, and transcription factors are secreted. Smad4 regulates the transcription of the target genes in the nucleus (28). The main transcription factors of embryonic stem cells in self-renewing and differentiation are Oct4, SOX2 and NANOG.

Activin A is another member of TGF- $\beta$ family. İt is necessary in pluripotentiality and self-renewing of embryonic stem cells. It induces Oct4, NANOG, Nodal, Wnt3, basic fibroblast growth factor (bFGF) and FGF8 and represses the BMP signals. Recently, TGF- $\beta$ activin sensitive SMADs which bind to the Nanog promoter region and increase Nanog promoter activity have been demonstrated. So these SMADs play an essential role in maintaining human embryonic stem cell self-renewing (27).

\section{Wingless-Wnt Signalling Pathway}

Wnt ligand Low density lipoprotein-related protein (LRP) 5/6 is a secreted glycoprotein which binds to serpertine receptors of the Frizzled family, forming complexes in the cell surface (26). In embryonic stem cells, Wnt signal pathways have an important role in controlling the cell transcription while providing the cell with polarity and enhancing proliferation also in embryonic stem cells differentiation and cell migration is supported by Wnt signals. In hematopoietic stem cell and progenitor cells, there is accumulating knowledge that Wnt signaling mechanisms are necessary for the self-renewal processes $(29,30)$.

Wnt cascade affects cells as three pathways, whom are:

1. Canonical Wnt pathway ( $\beta$-catenin pathway)

2. Noncanical Wnt pathway (Planar cell polarity pathway)

3. Wnt calcium pathway

In the active canonical Wnt signal pathway, the dephosphorilization of $\beta$-catenin is a key process by keeping $\beta$-catenin stable in the nucleus.Through embryonic development, the Wnt/ $\beta$-catenin signal pathway regulates the proliferation, and predestinates the embryonic neural stem cells. The ca- nonical Wnt/ $\beta$-catenin pathway has an important role in neurogenesis. When the Wnt signal pathway is activated, $\beta$-catenin is not phosphorylated, and it accumulates in cytosol. This accumulation enables $\beta$-catenin to pass the nuclear site. By $\beta$-catenin enterance transcription of target genes (Oct4, SOX2, NANOG) start. When Wnt inactive, $\beta$-catenin gets phosphorylated and binds to the destructive complex. Destruction of $\beta$-catenin suppresses the transcription of target genes $(31,32)$. Any defects in the regulation of the Wnt signal pathway can cause many abnormalities and diseases, such as abnormal activation of the Wnt $\beta$ catenin signal pathway that leads to a disorder called FAP (Familial Adenumatous Polipozis), which shows polyps in the colon and rectum (31).

\section{Notch Signalling Pathway}

The notch signalling pathway is important in predestination, and also in the continuity of embryonic and mature stem cells. It is necessary for self-renewal and stemness concepts of hematopoietic stem cells $(29,33)$. There are four types of notch receptor isoforms (Notch1-4). The canonical notch ligands are Jagged and Delta ligand families (Jag1, Jad2, DII1,DII3, DII4) (34). The notch signal pathway plays a role in the self-renewal of stem cell, and provides the antineurogenic signal during CNS development (35). Notch 1 signals have a critical role in cardiac development and life, in differentiation of cardiogenic stem and progenitor cells and, mutations in Notch 1 cause structural abnormalities in the heart, like bicuspid aortic valve (34).

\section{LIF-Stat3 Signalling Pathway}

LIF belongs to the IL- 6 cytokine family. It binds to the low affinity LIF receptor and the heterodimeric receptor composed of GP130 (36). This formed complex activates JAK (tyrosine kinasenound to Janus). LIF activates 3 pathways in the stem cell:

1- MAPK- differentiation

2- JAK/STAT- self-renewing

3- $\mathrm{PI}(3) \mathrm{K}$ - surviving (37)

Activation of LIF activates STAT3, and it provides, by affecting the target genes of embryonic stem cells (Oct4, NANOG, c-myc), the reproduction and self-renewal of the cell without differentiation. The Jak/STAT pathway also supports the self-renewal of hematopoietic stem cells. STAT3 contributes to the stemness and self-renewal of pluripotent stem cells by the transcription of target cells (38).

\section{Hippo Signalling Pathway}

Hippo signal pathway is important in the balancing of the preserving organ enlargement, cell self-renewing and cell proliferation. Deregulation of this pathway is related to the cancer development (39). It consists of serintreonin kinase MST1/2 (mammalian Ste-2 like kinase) and LATS1/2. The activation of the hippo pathway leads to the inactivation of YAP (Yes-asso- 
Table 1. Some environmental effects on MSC fate

\begin{tabular}{|c|c|}
\hline Environmental Factors & Some Effects on MSC \\
\hline \multirow[t]{2}{*}{ Geometry Mechanic Stress } & + Cell actin distribution cell elasticity \\
\hline & + partial loss of multipotentiality \\
\hline \multirow[t]{4}{*}{ High glucose level } & + markers of stemness are increased \\
\hline & + proliferation is decreased \\
\hline & + neurogenic differentiation in mature stem cell is significantly increased \\
\hline & + autophagia and senescence was induced in bone marrow derived MSCs \\
\hline \multirow[t]{3}{*}{ Ascorbic Acid } & + derivation to osteoblasts, adipocytes, chondrocytes and in vitro odontoblasts \\
\hline & + acceleration of DNA synthesis \\
\hline & + in high concentrations are cytotoxic, may cause the suppression of proliferation and apoptosis \\
\hline \multirow[t]{5}{*}{ Freezing\&Thawing } & + degenerated immune modulator characteristics and their inflammation rate is higher \\
\hline & + affects the immune modulator response \\
\hline & + heat shock protein (HSP) levels increase \\
\hline & + responds to inflammatory conditions decrease \\
\hline & + increase their immune modulator characteristics as a reply to inflammation \\
\hline \multirow[t]{3}{*}{ Hypoxia } & + potent stimulus invoking chondrogenesis \\
\hline & + stimulating therapeutically angiogenesis \\
\hline & + directly promotes wound healing \\
\hline
\end{tabular}

ciated protein). This YAP results in the direct phosphorylation ser-127. YAP and TAZ are co-activators of transcription. When LATS1/2 is dephosphorylated, YAP/TAZ is carried to the cell nucleus; it communicates with the transcription factors and induces the inhibition of cell proliferation and apoptosis. Embryonic stem cells YAP/TAZ directly supports stemness $(40,41)$. TAZ is connected to the Smad2,3,4 proteins in embryonic stem cells, thus it is effective in the self-renewal and proliferation of stem cells. Deletion of YAP leads to myocardial hypoplasia, loss of its function leads to cell death and early neuronal differentiation (41).

\section{Hedgehog Signalling Pathway}

This pathway is effective in self-renewal and regeneration of embryonic stem cells and mature stem cells. Hedhedog proteins have 3 different types of isoforms: Sonic (Shh), Desert (Dhh), Indian (Ihh). It is an active pathway both in embryonic and mature life (32). It plays a role in the proliferation and differentiation of embryonic stem cells, and in plerosis and regeneration of mature stem cells. It has a positive effect on osteogenic differentiation, and a negative effect on adipogenic differentiation $(32,42)$. Regulation of this pathway is responsible from holoprosencephaly and other developmental malformations (42).

\section{Mesenchymal Stem Cell and Interaction Factors}

In vivo MSCs are surrounded with extracellular matrix, which is composed of collagen, adhesion proteins, proteoglycans and growth factors called "niche". Besides the importance of molecular structures, physicochemical properties of microenvironment are also important in the differentiation of the stem cells. Some environmental effects are summarized, as seen in Table 1. Stem cells not only answer to the paracrine signals in their local microenvironment, but also undergo changes by being reactivated together with various matrix components, proteases and growth factors secreted from the medium. Matrix proteins play a role in cell adhesion, migration, differentiation and survival. Three dimensional matrix culture systems involving various growth factors in vitro are developed by mimicking in vivo systems (43). For example, the mesenchymal stem cell goes into osteogenic differentiation in a microenvironment with firmer elasticity and, goes into neuronal differentiation in a looser microenvironment (44). Niches for differentiation have been developed by considering these characteristics. It is supported in the studies that stem cells respond to the mechanical signals presented by the local extracellular matrix. Cells remember the previous mechanical signals, and this memory continues even after the translocation, and predestinates the long term (45). It is reported that with the important communication between 
extracellular matrix medium and intracellular signals, YAP and $T A Z$, by being located in the nucleus and by regulating the mRNA expression, turns the physical information into protein expression $(46,47)$.

MSCs are mechanosensitive cells. For example: meeting of MSCs with systemic circulation causes them to be exposed to flow stress, and this extracellular matrix mechanical stimulus is perceived by the sensors of the cell membranes; cell behavior is affected rapidly. G-protein coated receptors, intercellular and inter matrix proteins, integrines, and ion channels are mechanoreceptors playing a role in the intracellular kinase activity and the organization of the actinin cytoskeleton. Laminar flow is a type of flow that is unidirectional, stable, with various velocities and different from the flow in humans which is directed by the heart beats. Oscillatory flow and pulsatile flow are in the same direction, and their oscillations are at the same amplitude, but the mean rate of the pulsatile flow is higher than the rate of oscillatory flow. Oscillatory flow stress $\left(0.5 \pm 4 \mathrm{dyn} / \mathrm{cm}^{2}\right)$ affects the regulation of $\beta$-catenin and induces the reorganization of $f$-actin, and predestinates the stem cell. 30 minutes after oscillatory stress, $f$-actinindepolimerization and $\beta$-catenin increase make an adjuvant effect on the factors that inhibits the Wnt. After one hour of oscillatory stress, MSCs continue their fibroblast like appearance but the actin cytoskeleton organization changes. When the effect of oscillatory stress on stemness is searched by measuring the SOX2, Oct4 and NANOG levels, NANOG and SOX2 expressions were increased, and Oct4 expression was unchanged. Oscillatory stress promotes the adipogenic differentiation of MSCs (48).

\section{Geometry and Stem Cell Interaction}

Multipotentiality and self-renewal capacities of MSCs that are often used in clinical practice are important. The spread process of the stem cells in vitro culture decreases the multipotent capacity, and this limits the application in clinical practice. Geometric and mechanic control of stem cell spread regulates the differentiation and progression of stem cells (49). Culture size and geometric shape affect the stemness and the cytoskeleton and, the cellular stress formed in this structure affects the multipotentiality of the stem cell (49, $50)$. Many studies showed that cells respond to the reorganization of the cytoskeleton by biophysical stimulus (51). Cellular stress related to the cytoskeleton is important for the protection of stem cell multipotentiality. Cell elasticity is an important biomechanical parameter that is determined by the existence, number and distribution of specific organelles and by the organization and character of the cytoskeletal elements. Elasticity changes according to the cell functions. For example, fibroblasts have a high elasticity, and chondrocytes have a low elasticity. Elasticity of mature MSCs changes during differentiation (52). If actin structure is highly regular in the cell, elasticity becomes high. Sphere embryonic stem cells present higher Oct4 and NANOG expressions than squamous cells as a result of the loosened membrane-cytoskele- ton bounds. While a limited diffusion area has been shown to be helpful to save the undifferentiated form of embryonic stem cells, it has been identified that undifferentiated MSCs have lower contractility than differentiated osteogenic cells. So, this shows that a lower cytoskeletal stress is needed in order to protect the cell multipotentiality. It has also been shown that as the cell's area of diffusion enlarges, the cell's nuclear activity also increases. Parallel stress fibers formed in the slim shaped cells renders the elasticity of MSCs. In different geometric areas (e.g. square, triangle, polygon) MSCs in their center have shown an interrupted actin form which causes low elasticity. Cell diffusion showed similar responses in different geometric areas, if the distribution area is the same. High elasticity of MSCs always exists with low expression of surface molecules, and this shows the partial loss of multipotentiality (49).

\section{Culture and Stem Cell Interaction}

The culture medium necessary for feeding and growing of the stem cell is very important in order for them to release their biological effects. Gas percentages $\left(\mathrm{O}_{2}-\mathrm{CO}_{2}-\mathrm{N}\right)$ and the composition of culture medium (e.g. ph, glucose concentration), cell number in every $\mathrm{cm}^{2}$, passage time and number, are some important parameters. Fetal Bovine Serum (FBS) has a risk of virus and prion contamination between media, so alternatively, serum-free media are produced with growth factors additions (53). Yet, medium prepared with serum based on autologous source is a good alternative for MSC cultures. The main problem is the identification of serum percentages. Platelet lysate, which is rich in cytokines and growth factors invitro MSC cultures, is a candidate for the usage of FBS (54). Various molecules are stored in platelet granules. Some of these are lysosomal enzymes (elastase, collagenase, catepsine), coagulation factors (factor $\mathrm{V}, \mathrm{XI}, \mathrm{XIII}$, antithrombin, prothrombin), immunological molecules (IgG, factor $D$, platelet factor $\mathrm{H}, \mathrm{C} 1$ inhibitor), adhesion molecules (P selectin, fibrinogen, VWF), chemokines (IL8, RANTES, NAP2), growth and angiogenesis regulators (55). Enriched platelet products like Platelet rich plasma (PRP), Platelet lysate $(\mathrm{PL})$ or platelet gel include various growth factors like platelet derived growth factors (PDGFs), TGF- $\beta$, epidermal growth factor (EGF) and bFGF. These growth factors influence MSCs to mitosis. It is shown that cells obtained at the end of cultures stimulate invivo angiogenesis, and play a key role in tissue repair and regeneration $(56,57)$.

MSCs are traditionally isolated from bone marrow and adipose tissue, and they form fibroblast like cell colonies sticking the plastic in 2-dimensional in vitro cultures. While 2-dimensional cultures are artificial and less physiological, 3-dimensional spheroid shaped cultures save more physiological features. Anti-inflammatory, angiogenic, repair and regeneration effects of MSCs are more expanded in spheroid cultures than in 2-dimensional cultures. Oxygen reaches inside the spheroids with only diffusion, which causes the inner cell mass of 
the spheroid hypoxic. This condition activates the pathways connected to hypoxia (58). Also, upregulation of the genes showing pluripotentiality enhances multidifferentiation potentiality together with the slowing of the senescence, increases stemness.

\section{Culture and High Glucose Level}

Glucose is the vital energy source which is critically important for the biological functions of the cells in culture media. Diabetic hyperglycemic medium is a phenomenon which induces the differentiation in MSCs. Oct4, SOX2 and NANOG gene expressions, which are the markers of stemness, are increased under prolonged high glucose conditions, and their proliferation is decreased. This may be due to reactive oxygen species (ROS) increase, and cultures with low glucose level demonstrated decreased stemness and increased proliferation. Even though diabetic mature stem cells are not the ideal autologous cell therapy because of its degenerated neovascular structure, stemness and differentiation capacities of the mature stem cells in hyperglycemic media are still researched. The inhibition of stemness and proliferation induced by high glucose level is thought to be inhibited by ROS in the environment and, this effect is tried to be decreased by the added antioxidants to the medium. But, this also decreased the positive effects of high glucose on the stemness of stem cell. It is observed that the ratio of neurogenic differentiation in mature stem cell is significantly increased in a high glucose medium, but the potential of adipogenic and osteogenic differentiation does not change. High glucose level, just like hypoxia, medium deprivation and low temperature, is a cellular stress condition which increases the stemness capacity (6). MSCs based on adipose tissue advances adipogenesis more in a high level glucose medium than in a low level glucose medium. In MSCs treated with a high glucose culture, it was shown that chondrogenesis was modulated by ensuring the regulation of TGF- $\beta$ and protein kinase $C$ (59). While the chondrogenic capacity increases, the adipogenic capacity decreases. In another study (60), MSCs treated with a high level glucose medium ( $4.5 \mathrm{gr} / \mathrm{L}$ ) for 28 days and it was shown that autophagia and senescence were induced in bone marrow derived MSCs.

\section{Culture and Ascorbic Acid}

Cell metabolism in microenvironment is closely related to the metabolic interactions between different types of cells. When cells are isolated in their actual tissues and cultured, their nutrient needs change, and this need is different for every cell. Ascorbic acid ( $A A)$ increases the stimulation effect of in vitro cells for intercellular matrix production, and it is understood that it has an important role as a cofactor for the posttranslational modification of AA collagen molecules. It is known that AAs modulates the proliferation of many mesenchymal derived cells including osteoblasts, adipocytes, chondrocytes and in vitro odontoblasts. AA works as a growth supporter for the proliferation of the cells and acceleration of DNA synthesis, when it is added to the cultural medium in defined concentrations. But, prominently high concentrations are cytotoxic, and may cause the suppression of proliferation and apoptosis. This relation between cytotoxicity and ascorbic acid is defined by the medium related factors like type of the medium and $\mathrm{CO}_{2}$ ratio (61). AAs, while increasing the regulation of embryonic stem cell pluripotent markers (Oct4 and SOX2), also induce the proliferation of MSCs based on adipose tissue and, this in vitro proliferation expansion is necessary for their use in stem cell therapy (62). Performed studies showed that Vitamin $C$ is a necessary agent for the proliferation of both embryonic and mature stem cells (63).

\section{The Effect of Freezing and Thawing on Stem Cells}

With the usage of MSCs in the treatment of degenerative and immunological diseases, further research studies are being conducted for effective treatment methods. After the culture diffusion and isolation of MSCs, they are frozen until brought into use. This process is called cryopreservation. Phenotypical and functional characteristics of the cells are important for the effectiveness and safety of stem cell therapy. After the freezing-thawing process, some characters of MSCs may change. Expected results of in vitro and preclinical studies do not always coincide with clinical practices. This may be due to various reasons. Cultured MSCs may not always be compatible with human blood, and when applied intravenously, it may trigger sudden inflammation. As a result of this, on one hand cell survival is conceded, and on the other hand the beneficial paracrine effects increase. MSCs that come directly from a culture flask, frozen and thawed just before usage, show significant differences. Freeze\&thawed MSCs have degenerated immune modulator characteristics, and their inflammation rate is higher (64). It is observed that in the first 24 hours of thawed MSCs, heat shock protein (HSP) levels increase, and the response to inflammatory conditions decreases (65). It is shown that the cryopreservation process has a little effect on gene expressions. Unlike traditional medical therapies metabolized by the recipient, cells responding to the microenvironment may undergo dramatic changes in MSC therapy. Freezing\&Thawing affects the immune modulator response in MSCs. MSC functions have been completely saved after 24 hours of culture period. After one week of the thawing process, minimal changes in MSC gene expressions have been identified. Cytoskeletal reorganization has occurred and genes including natural immune pathways have undergone changes. Frozen cells have been kept for one week after thawing, and the induction of the increase in cytoskeletal protein expression became possible. The essential question is how this phenotypical changes affecting the functions of MSCs occur. As it is known, MSCs increase their immune modulator characteristics as a reply to inflammation. Increase in the expression of cytokine families, respectively IL11, IL33, IL6 and IL1, is proof of the activation of immunological signal pathways (9). 


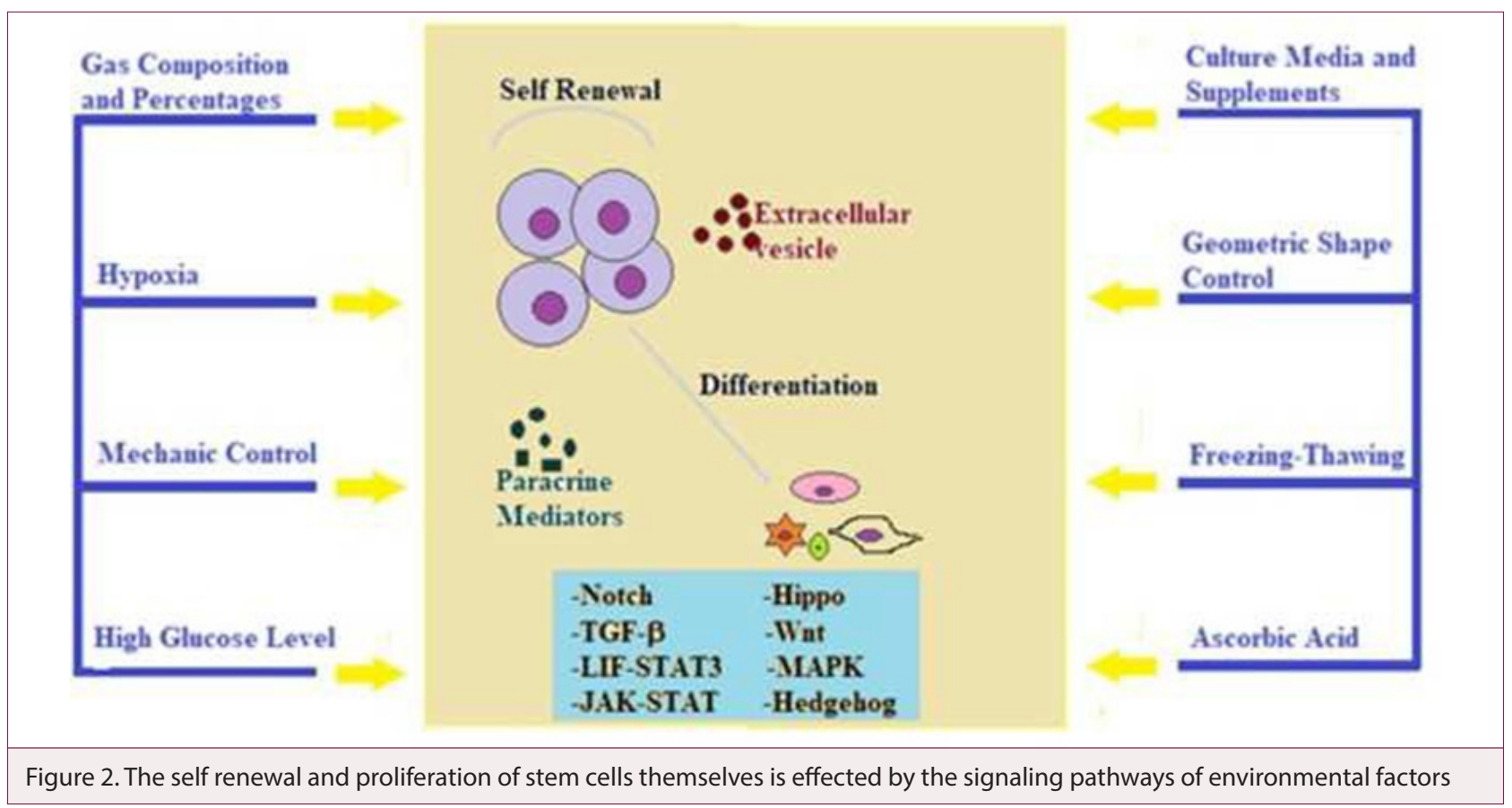

\section{Hypoxia}

Oxygen concentration is a very important factor for the maintenance, differentiation and function of stem cells. Oxygen has various effects on embryonic and mature stem cells. Hypoxia plays a role in growth, pluripotentiality, differentiation and growth factor production. Molecular oxygen has characteristics of being a signal molecules and metabolic substrat, both in vivo and in vitro. The effects of oxygen, self-renewing, differentiation and final function are not completely understood, astheir effects modify according to the cell type and oxygen level. In some mature cell types, a low oxygen level stimulates in vitro proliferation and multipotentiality. Low oxygen level is a potent stimulus invoking chondrogenesis in stem cells and in a clinical course, and it is important for functional cartilage production in engineering. Hypoxia also plays an important role in therapeutic angiogenesis by stimulating cytokine production. When stem cells are exposed to hypoxia, it is shown that growth factor, and especially VEGF production, increase. Angiogenesis formed by hypoxia can be both by differentiation of cells directly, or by cytokine production indirectly. In order to understand and optimize the growth functions of the stem cells, it is important to know specific microenvironment conditions in vivo. Interpreting in vitro experiments containing stem cells shows the need for a minute oxygen level (19). Embryonic stem cell lives under low oxygen levels in the beginning of implementation and during fetal growth. Blocking to reach maternal circulation during embryo implementation results in a hypoxic environment. Uterine surface oxygen concentration is at around $2 \%$ level during early the pregnancy period. When the embryo connects with the maternal vessels, the oxygen level rises to approximately $8 \%$. That is why normal physiologic conditions of the embryonic stem cells are more hypoxic compared to in vitro conditions. Oxygen is an important signal molecule that stimulates cellular activity. Hypoxia increases the specific gene expressions (Glut-1,EPO,VEGF) comprising glycolysis, erythropoiesis and angiogenesis. VEGF produced by stem cell in hypoxic environment directly affects the surrounding environment (66). Highly perfused organs (e.g. lungs, kidney and liver) have oxygen levels between 4 and 14\%. But this level is low in bone marrow (between 0 and 4\%). It is especially lower than $3 \%$ in adipose tissue. Mature stem cells are located in anatomical regions which have relatively poor levels of oxygen. Both mature and embryonic stem cells express surface markers (Oct4, rex-1 and SOX2) at least for ten passages. Mature stem cell expresses different surface molecules; these are adhesion molecules, receptor molecules, surface enzymes, extracellular matrix proteins and glycoproteins (67). Hypoxia, by some paracrine mechanism which increases the secretion of defined growth factors, advances neoangiogenesis in mature stem cells. The primary mediator of hypoxic adaptation is Hypoxia inducible factor (HIF). It is from transcription factor family and has two subunits: alpha subunit (HIF-1 a and HIF-2 a) and beta subunit (HIF-1 $\beta$ ).HIF-1 $\beta$ is physically connected to the intracellular region of notch molecule and it is an important component in order to protect undifferentiated stem and progenitor cell populations which are providing an impressive molecular connection between hypoxia and stemness (68). HIF-2 is the transcriptional regulator in embryonic stem cell pluripotentiality and it has a connection with Oct4. HIF-2 a directly connects to Oct4, SOX2, hypoxic response elements (HRE) in the Nanog promoter region in hypoxic conditions (69). Alpha subunit of HIF-1 is stabilized under low oxygen levels and by regulation VEGF expression, it provides functional harmony and characteristics which are necessary for new vascular 
growth and maturation. At the same time HIF-1 a, increases dramatically by hypoxia, enhances angiogenic and antiapoptotic growth factors, and this directly promotes wound healing. $\mathrm{HIF}-1$ a rising related increase of $\mathrm{Myc}$, which is a transcriptional factor, affects metabolism with the increase of pleiotropic, proliferative and cell growth factors (70). HIF-1 a directly affects the Wnt/ beta-catenin pathway, and so presents its effect on both embryonic and mature stem cells (68).

\section{CONCLUSION}

This article reviews the current knowledge of the mesenchymal stem cell signaling pathways and interactions of stem cells with each other in culture. The more cell culture parameters can be optimized; the better the intercellular signaling pathways will work (Figure 2). Although this requires further investigation, it is essential to achieve the desired success in cell culture techniques. The parameters of cell culture to be considered are much more than what we describe in this paper.

Peer-review: Externally peer-reviewed.

Author Contributions: Concept - G.Ç., S.D., T.M.A.; Supervision - G.Ç., S.D., T.M.A.; Materials - G.Ç., S.D., T.M.A.; Data Collection and/or Processing - G.Ç., S.D., T.M.A.; Analysis and/or Interpretation - G.Ç., S.D., T.M.A.; Literature Search - G.Ç., S.D., T.M.A.; Writing - G.Ç., S.D., T.M.A.; Critical Reviews - G.Ç., S.D., T.M.A.

Conflict of Interest: The authors have no conflict of interest to declare.

Financial Disclosure: The authors declared that this study has received no financial support.

\section{Hakem Değerlendirmesi: Dış bağımsız.}

Yazar Katkıları: Fikir - G.Ç., S.D., T.M.A.; Denetleme - G.Ç., S.D., T.M.A.; Gereçler - G.Ç., S.D., T.M.A.; Veri Toplanması ve/veya İşlemesi - G.Ç., S.D., T.M.A.; Analiz ve/veya Yorum - G.Ç., S.D., T.M.A.; Literatür Taraması - G.Ç., S.D., T.M.A.; Yazan - G.Ç., S.D., T.M.A.; Eleştirel İnceleme - G.Ç., S.D., T.M.A.

Çıkar Çatışması: Yazarlar çıkar çatışması bildirmemişlerdir.

Finansal Destek: Yazarlar bu çalışma için finansal destek almadıklarını beyan etmişlerdir.

\section{REFERENCES}

1. Abraham L, Kierszenbaum MD, Laura L. Tres, Cell Signaling, in Histology and Cell Biology. An Introduction to Pathology. Elsevier 2012. p. 89-109. [CrossRef]

2. Gündeşlioğlu AÖ, Altuntaş Z, İnce B, Dadacı M, Aktan M, Duman S. Adipose Tissue Derived Stem Cells and Their Uses in Plastic Surgery. Turk Plast Surg 2013; 21: 1-10.

3. Aktan TM, Duman S, Cihantimur B. Cellular and molecular aspects of adipose tissue. In: Illouz YG, Sterodimas A, editors. Adipose Stem Cells and Regenerative Medicine. Springer; 2011. p. 1-12. [CrossRef]

4. Duman S, Aktan TM, Cüce G, Cihantimur B, Tokaç M, Akbulut H. Effects of Lipokit ${ }^{\oplus}$ Centrifugation on Morphology and Resident Cells of Adipose Tissue. Int J Morphol 2013; 31: 64-9. [CrossRef]
5. Akbulut H, Cüce G, Aktan TM, Duman S. Expression of mesenchymal stem cell markers of human adipose tissue surrounding the vas deferens. Biomed Res 2012; 23: 0970-938X.

6. Cheng NC, Hsieh TY, Lai HS, Young TH. High glucose-induced reactive oxygen species generation promotes stemness in human adipose-derived stem cells. Cytotherapy 2016; 18: 371-83. [CrossRef]

7. Abels ER, Breakefield XO. Introduction to Extracellular Vesicles: Biogenesis, RNA Cargo Selection, Content, Release, and Uptake. Cell Mol Neurobiol 2016; 301-12. [CrossRef]

8. Katsuda T, Ochiya T. Molecular signatures of mesenchymal stem cell-derived extracellular vesicle-mediated tissue repair. Stem Cell Res Ther 2015; 6: 212. [CrossRef]

9. Hoogduijn MJ, de Witte SF, Luk F, et al. Effects of Freeze-Thawing and Intravenous Infusion on Mesenchymal Stromal Cell Gene Expression. Stem Cells Dev 2016; 25: 586-97. [CrossRef]

10. Lai RC, Arslan F, Tan SS, Tan B, Choo A, Lee MM, et al. Derivation and characterization of human fetal MSCs: an alternative cell source for large-scale production of cardioprotective microparticles. J Mol Cell Cardiol 2010; 48: 1215-24. [CrossRef]

11. Lai RC, Arslan F, Lee MM, Sze NS, Choo A, Chen TS, et al. Exosome secreted by MSC reduces myocardial ischemia/reperfusion injury. Stem Cell Res 2010; 4: 214-22. [CrossRef]

12. Tokac M, Aktan M, Ak A, Duman S, Tokgozoglu L, Aygul N, et al. Autologous transplantation of arterial cells improves cardiac function in a rabbit model of infarcted myocardium. Stem Cells Dev 2010;19: 927-34. [CrossRef]

13. Zhang B, Wang M, Gong A, Zhang X, Wu X, Zhu Y, et al. HucMSCExosome Mediated-Wnt4 Signaling Is Required for Cutaneous Wound Healing. Stem Cells 2015; 33: 2158-68. [CrossRef]

14. Gatti S, Bruno S, Deregibus MC, Sordi A, Cantaluppi V, Tetta C, et al. Microvesicles derived from human adult mesenchymal stem cells protect against ischaemia-reperfusion-induced acute and chronic kidney injury. Nephrol Dial Transplant 2011; 26: 1474-83. [CrossRef]

15. Bruno S, Grange C, Collino F, Deregibus MC, Cantaluppi V, Biancone $L$, et al. Microvesicles derived from mesenchymal stem cells enhance survival in a lethal model of acute kidney injury. PloS one 2012; 7: e33115. [CrossRef]

16. Zhu YG, Feng XM, Abbott J, Fang XH, Hao Q, Monsel A, et al. Human mesenchymal stem cell microvesicles for treatment of Escherichia coli endotoxin-induced acute lung injury in mice. Stem cells 2014; 32: 116-25. [CrossRef]

17. Arreba-Tutusaus $P$, Heidel FH. Signaling Pathways Maintaining Stemness in Adult Hematopoietic Stem Cells. In: Kursad Turksen, editors. Adult Stem Cells 2014; Springer. p. 1-12. [CrossRef]

18. Zon LI. Intrinsic and extrinsic control of haematopoietic stem-cell self-renewal. Nature 2008; 453: 306-13. [CrossRef]

19. Virant-Klun I, Stimpfel M, Skutella T. Adult Ovary Stem Cells. In: Kursad Turksen, editors. Adult Stem Cells 2014; Springer. p. 23964. [CrossRef]

20. Mathieu J, Ruohola-Baker H. Regulation of stem cell populations by microRNAs. Adv Exp Med Biol 2013; 786: 329-51. [CrossRef]

21. Kallas A, Pook M, Trei A, Maimets T. SOX2 is regulated differently from NANOG and OCT4 in human embryonic stem cells during early differentiation initiated with sodium butyrate. Stem Cells Int 2014; doi: 10.1155/2014/298163. [CrossRef]

22. Rodda DJ, Chew JL, Lim LH, Loh YH, Wang B, et al. Transcriptional regulation of nanog by OCT4 and SOX2. J Biol Chem 2005; 280: 24731-7. [CrossRef]

23. Wu G, Schöler HR. Role of Oct4 in the early embryo development. Cell Regen 2014; 3: 7. [CrossRef] 
24. Dubon MJ, Yu J, Choi S, Park KS. Transforming growth factor $\beta$ induces bone marrow mesenchymal stem cell migration via noncanonical signals and N-cadherin. J Cell Physiol 2018; 233: 201-13. [CrossRef]

25. Avery S, Zafarana G, Gokhale PJ, Andrews PW. The role of SMAD4 in human embryonic stem cell self-renewal and stem cell fate. Stem Cells 2010; 28: 863-73. [CrossRef]

26. Cadigan KM, Liu YI. Wnt signaling: complexity at the surface. J Cell Sci 2006; 119: 395-402. [CrossRef]

27. Jiang J, Ng HH. TGF $\beta$ and SMADs talk to NANOG in human embryonic stem cells. Cell Stem Cell 2008; 3: 127-8. [CrossRef]

28. Orlowski J. SMAD5 signaling: more than meets the nuclei. Cell Res 2017; 27: 1075-6. [CrossRef]

29. Katoh $M$, Katoh M. WNT signaling pathway and stem cell signaling network. Clin Cancer Res 2007; 13: 4042-5. [CrossRef]

30. Hülsken J, Behrens J. The Wnt signalling pathway. J Cell Sci 2000; 113: 3545 .

31. Nusse R. Wnt signaling in disease and in development. Cell Res 2005; 15: 28-32. [CrossRef]

32. Chen Q, Shou P, Zheng C, Jiang M, Cao G, Yang Q, et al. Fate decision of mesenchymal stem cells: adipocytes or osteoblasts? Cell Death Differ 2016; 23: 1128-39. [CrossRef]

33. Evans AG, Calvi LM. Notch signaling in the malignant bone marrow microenvironment: implications for a niche-based model of oncogenesis. Ann N Y Acad Sci 2015; 1335: 63-77. [CrossRef]

34. Penton AL, Leonard LD, Spinner NB. Notch signaling in human development and disease. Semin Cell Dev Biol 2012; 23: 450-7. [CrossRef]

35. Zhang K, Zhu L, Fan M. Oxygen, a key factor regulating cell behavior during neurogenesis and cerebral diseases. Front Mol Neurosci 2011; 4: 1-11. [CrossRef]

36. Koide H, Yokota T. The LIF/STAT3 Pathway in ES Cell Self-renewal. Embryonic stem cells-The hormonal regulation of pluripotency and embryogen-esis. Rijeka 2011: InTech: p. 61-78. [CrossRef]

37. Nicola NA, Babon JJ. Leukemia inhibitory factor (LIF). Cytokine Growth Factor Rev 2015; 26: 533-44. [CrossRef]

38. Stine RR, Matunis EL. JAK-STAT signaling in stem cells. Adv Exp Med Biol 2013; 786: 247-67. [CrossRef]

39. Park JH, Shin JE, Park HW. The Role of Hippo Pathway in Cancer Stem Cell Biology. Mol Cells 2018; 41: 83.

40. Mo JS, Park HW, Guan KL. The Hippo signaling pathway in stem cell biology and cancer. EMBO Rep 2014; 15: 642-56. [CrossRef]

41. Ramos A, Camargo FD. The Hippo signaling pathway and stem cell biology. Trends Cell Biol 2012; 22: 339-46. [CrossRef]

42. Briscoe J, Thérond PP. The mechanisms of Hedgehog signalling and its roles in development and disease. Nat Rev Mol Cell Biol 2013; 14: 416-29. [CrossRef]

43. Rakian R, Block TJ, Johnson SM, Marinkovic M, Wu J, Dai Q, et al. Native extracellular matrix preserves mesenchymal stem cell "stemness" and differentiation potential under serum-free culture conditions. Stem Cell Res Ther 2015; 6: 1-11. [CrossRef]

44. Brizzi MF, Tarone G, Defilippi P. Extracellular matrix, integrins, and growth factors as tailors of the stem cell niche. Curr Opin Cell Biol 2012; 24: 645-51. [CrossRef]

45. Gilbert PM, Havenstrite KL, Magnusson KE, Sacco A, Leonardi NA, et al. Substrate elasticity regulates skeletal muscle stem cell self-renewal in culture. Science 2010; 329: 1078-81. [CrossRef]

46. Dupont S, Morsut L, Aragona M, Enzo E, Giulitti S, Cordenonsi M, et al. Role of YAP/TAZ in mechanotransduction. Nature 2011;474: 179-83. [CrossRef]
47. Yang C, Tibbitt MW, Basta L, Anseth KS. Mechanical memory and dosing influence stem cell fate. Nat Mater 2014; 13: 645-52. [CrossRef]

48. Kuo YC, Chang TH, Hsu WT, Zhou J, Lee HH, Hui-Chun Ho J, et al. Oscillatory shear stress mediates directional reorganization of actin cytoskeleton and alters differentiation propensity of mesenchymal stem cells. Stem Cells 2015; 33: 429-42. [CrossRef]

49. Wang X, Nakamoto T, Dulińska-Molak I, Kawazoea N, Chen G. Regulating the stemness of mesenchymal stem cells by tuning micropattern features. J Mater Chem B 2016; 4: 37-45. [CrossRef]

50. Wan LQ, Kang SM, Eng G, Grayson WL, Lu XL, Huo B, et al. Geometric control of human stem cell morphology and differentiation. Integr Biol (Camb) 2010; 2: 346-53. [CrossRef]

51. Engler AJ, Sen S, Sweeney HL, Discher DE. Matrix elasticity directs stem cell lineage specification. Cell 2006; 126: 677-89. [CrossRef]

52. Kiss R, Bock H, Pells S, Canetta E, Adya AK, Moore AJ, et al. Elasticity of human embryonic stem cells as determined by atomic force microscopy. J Biomech Eng 2011; 133:101009. [CrossRef]

53. van der Sanden B, Dhobb M, Berger F, Wion D. Optimizing stem cell culture. J Cell Biochem 2010; 111: 801-7. [CrossRef]

54. Siciliano C, Ibrahim M, Scafetta G, Napoletano C, Mangino G, Pierelli $L$, et al. Optimization of the isolation and expansion method of human mediastinal-adipose tissue derived mesenchymal stem cells with virally inactivated GMP-grade platelet lysate. Cytotechnology 2015; 67: 165-74. [CrossRef]

55. Burnouf T, Strunk D, Koh MB, Schallmoser K. Human platelet lysate: Replacing fetal bovine serum as a gold standard for human cell propagation? Biomaterials 2016; 76: 371-87. [CrossRef]

56. Schallmoser K, Bartmann C, Rohde E, Reinisch A, Kashofer K, Stadelmeyer $E$, et al. Human platelet lysate can replace fetal bovine serum for clinical-scale expansion of functional mesenchymal stromal cells. Transfusion 2007; 47: 1436-46. [CrossRef]

57. Cobden SB, Oztürk K, Duman S, Esen H, Aktan TM, Avunduk MC, et al. Treatment of Acute Vocal Fold Injury With Platelet-Rich Plasma. JVoice 2015; 30: 731-5. [CrossRef]

58. Cesarz Z, Tamama K. Spheroid Culture of Mesenchymal Stem Cells. Stem Cells Int 2016; doi: 10.1155/2016/9176357. [CrossRef]

59. Tsai TL, Manner PA, Li WJ. Regulation of mesenchymal stem cell chondrogenesis by glucose through protein kinase C/transforming growth factor signaling. Osteoarthritis Cartilage 2013; 21: 36876. [CrossRef]

60. Chang TC, Hsu MF, Wu KK. High glucose induces bone marrow-derived mesenchymal stem cell senescence by upregulating autophagy. PloS one 2015; 10: e0126537. [CrossRef]

61. Choi KM, Seo YK, Yoon HH, Song KY, Kwon SY, Lee HS, et al. Effect of ascorbic acid on bone marrow-derived mesenchymal stem cell proliferation and differentiation. J Biosci Bioeng 2008; 105: 58694. [CrossRef]

62. Potdar PD, D'Souza SB. Ascorbic acid induces in vitro proliferation of human subcutaneous adipose tissue derived mesenchymal stem cells with upregulation of embryonic stem cell pluripotency markers Oct4 and SOX 2. Hum Cell 2010; 23: 152-5. [CrossRef]

63. Li CJ, Sun LY, Pang CY. Synergistic protection of $\mathrm{N}$-acetylcysteine and ascorbic acid 2-phosphate on human mesenchymal stem cells against mitoptosis, necroptosis and apoptosis. Sci Rep 2015; 5: 9819. [CrossRef]

64. Moll G, Alm JJ, Davies LC, von Bahr L, Heldring N, Stenbeck-Funke $L$, et al. Do cryopreserved mesenchymal stromal cells display impaired immunomodulatory and therapeutic properties? Stem cells 2014; 32: 2430-42. [CrossRef] 
65. François M, Copland IB, Yuan S, Romieu-Mourez R, Waller EK, Galipeau J. Cryopreserved mesenchymal stromal cells display impaired immunosuppressive properties as a result of heat-shock response and impaired interferon- $\gamma$ licensing. Cytotherapy 2012; 14: 147-52. [CrossRef]

66. Abdollahi H, Harris LJ, Zhang P, Mcllhenny S, Srinivas V, Tulenko T, et al. The role of hypoxia in stem cell differentiation and therapeutics. J Surg Res 2011; 165: 112-7. [CrossRef]

67. Chung HM, Won $\mathrm{CH}$, Sung JH. Responses of adipose-derived stem cells during hypoxia: enhanced skin-regenerative potential. Expert Opin Biol Ther 2009; 9: 1499-508. [CrossRef]
68. Larochelle A. Cord blood culture in hypoxia: making the cells feel at home. Cytotherapy 2012; 14: 900-1. [CrossRef]

69. Petruzzelli R, Christensen DR, Parry KL, Sanchez-Elsner T, Houghton FD. HIF-2a regulates NANOG expression in human embryonic stem cells following hypoxia and reoxygenation through the interaction with an Oct-Sox cis regulatory element. PloS One 2014; 9: e108309. [CrossRef]

70. Hubbi ME, Semenza GL. Regulation of cell proliferation by hypoxia-inducible factors. Am J Physiol Cell Physiol 2015; 309: 775-82. [CrossRef] 